\title{
Genistein inhibits aggregation of exogenous amyloid-beta(1-40) and alleviates astrogliosis in the hippocampus of rats.
}

Maryam Bagheri, Mehrdad Roghani, Mohammad-Taghi Joghataei and Simin Mohseni

\section{Linköping University Post Print}

N.B.: When citing this work, cite the original article.

Original Publication:

Maryam Bagheri, Mehrdad Roghani, Mohammad-Taghi Joghataei and Simin Mohseni, Genistein inhibits aggregation of exogenous amyloid-beta(1-40) and alleviates astrogliosis in the hippocampus of rats., 2012, Brain Research, (1429), 145-154.

http://dx.doi.org/10.1016/j.brainres.2011.10.020

Copyright: Elsevier http://www.elsevier.com/

Postprint available at: Linköping University Electronic Press

http://urn.kb.se/resolve?urn=urn:nbn:se:liu:diva-72775 
Genistein inhibits aggregation of exogenous amyloid-beta ${ }_{1-40}$ and alleviates astrogliosis in the hippocampus of rats

Maryam Bagheri $^{1,2}$, Mehrdad Roghani ${ }^{3}$, Mohammad-Taghi Joghataei ${ }^{2}$, Simin Mohseni ${ }^{1}$

${ }^{1}$ Department of Clinical and Experimental Medicine, Faculty of Health Sciences, Linköping

University, Linköping, Sweden

${ }^{2}$ Cellular and Molecular Research Center \& Department of Anatomy and Neuroscience, School of Medicine, Tehran University of Medical Sciences, Tehran, Iran

${ }^{3}$ Department of Physiology and Medicinal Plant Research Center, Shahed University, Tehran, Iran

\section{Corresponding authors:}

Maryam Bagheri, MSc., graduate student

Division of Cell Biology, Linköping University, SE-581 85 Linköping, Sweden

E-mail: Maryam.bagheri@liu.se

Telephone: +46 101034144

Fax: +46 101033192

Mohammad-Taghi Joghataei, Professor

Cellular and Molecular Research Center, Tehran University of Medical Sciences (Hemmat Campus), Hemmat Highway, Tehran, Iran

E-mail: joghataei@tums.ac.ir

Fax: +98 2188058689 . 


\section{Abstract}

We addressed the question of whether injection of $A \beta_{1-40}$ in the rat brain is associated with pathology in the hippocampus, and if genistein has any protective effect against the neuronal damage caused by $A \beta_{1-40}$. Genistein is a plant-derived compound with a structure similar to that of the female sex hormone oestrogen and it was recently shown that pretreatment with a single dose of genistein ameliorated learning and memory deficits in an amyloid beta $(\mathrm{A} \beta)_{1-40}$ rat model of Alzheimer's disease. Here, we report that injection of the amyloid peptide into the hippocampus of rats led to formation of $A \beta_{1-40}$ positive aggregates close to the lateral blade of the dentate gyrus (DGlb). We also observed the following in the hippocampus: extensive cell death in the DGlb $(P<0.0001)$, CA1 $(P=0.03)$, and CA3 $(P=0.002)$; an increased number of iNOS-expressing cells $(P=0.01)$ and gliosis. Genistein given to rats by gavage one hour before injection of $A \beta_{1-40}$ inhibited the formation of $A \beta_{1-40}$ positive aggregates in the brain tissue and led to increased number of $\operatorname{nNOS}^{+}(P=0.0001)$ cells in the hippocampus compared to shamoperated genistein-treated controls. Treatment with genistein also alleviated the extensive astrogliosis that occurred in $A \beta_{1-40}$-injected hippocampus to a level similar to that observed in sham-operated rats. We conclude that the neurons in the DGlb are most sensitive to $\mathrm{A} \beta_{1-40}$, and a single dose of genistein can ameliorate $\mathrm{A} \beta_{1-40}$ induced pathology.

Key words: amyloid-beta, Alzheimer's disease, genistein, neuronal degeneration 1

\footnotetext{
${ }^{1}$ Abbreviations: AD, Alzheimer's disease; iNOS, inducible nitric oxide synthase; $\boldsymbol{n N O S}$, neuronal nitric oxide synthase; $\boldsymbol{C A 1}$, cornu ammonis 1; $\boldsymbol{C A 2}$, cornu ammonis 2; $\boldsymbol{C A}$, cornu ammonis 3; $\boldsymbol{A} \boldsymbol{\beta}$, amyloid beta; $\boldsymbol{D} \boldsymbol{G l b}$, lateral blade of dentate gyrus; $\boldsymbol{D G} \boldsymbol{m b}$, medial blade of dentate gyrus; $\boldsymbol{G F A P}$, glial fibrillary acidic protein; $\boldsymbol{C C}$, corpus callosum; $\boldsymbol{M A P}$, mitogenactivated protein; $\boldsymbol{N F \boldsymbol { K } B}$, nuclear factor kappa B; $\mathbf{M n S O D}$, manganese superoxide dismutase; $\boldsymbol{A P P}$, amyloid precursor protein; $\boldsymbol{C r} \boldsymbol{E} \boldsymbol{L}$, Cremophor EL
} 


\section{Introduction}

In patients with Alzheimer's disease (AD), the brain shows extracellular $\beta$-amyloid $(\mathrm{A} \beta)$ deposition as well as intracellular neurofibrillary tangles. Dystrophic neuritis, synaptic loss, and neuronal death are additional pathological hallmarks of AD. Much of the research on the pathogenesis of this disease has focused on the role of abnormally high amyloid secretion, which is believed to be the central event in neuronal degeneration. In vitro, the presence of $A \beta$ is associated with degeneration of neurites (Horiuchi et al., 2010), and overexpression of $A \beta$ in transgenic mice induces neuronal degeneration consistent with that observed in Alzheimer's patients (Games et al., 1995). Also injection of $A \beta$ into the rat brain causes neuronal damage (Miguel-Hidalgo et al., 1998; Miguel-Hidalgo et al., 2002). Even though much progress has been made in elucidating the biological mechanism of development of this disease, there is still no cure. The increasing number of patients suffering from $\mathrm{AD}$ throughout the world (Fratiglioni et al., 2010) indicates an urgent need for preventive measures and effective therapy.

Soy protein contains a large amount of isoflavones which are associated with a wide variety of beneficial health effects. One of the best-known isoflavones i.e. genistein is absorbed in the small intestine (Picherit et al., 2000), can be detected in plasma and serum after oral administration (Rowland et al., 2003), and crosses the blood-brain barrier (Tsai, 2005). Genistein has a structure similar to $17 \beta$-oestradiol, and it can bind to the oestrogen receptors (Lephart et al., 2004). Oestrogen offers some protection against $A \beta$-induced cell death, but it also has serious oncogenic effects on non-neuronal cells (Bang et al., 2004), and thus renders this hormone of limited use for treatment purposes. Genistein may have a beneficial influence similar to that of 
oestrogen but without the negative side effects (Bang et al., 2004). Genistein acts via oestrogen receptors to stimulate MAP kinases; these proteins activate the NFKB signaling pathway and thereby induce overexpression of manganese superoxide dismutase (MnSOD), which serves as antioxidant in the cell (Akiyama et al., 1987; Borras et al., 2006). Recently, Huang and Zhang (Huang and Zhang, 2010) observed that chronic ingestion of genistein reduced neuronal apoptosis in the brain of ovariectomized rats. Furthermore, Valles and colleagues (Valles et al., 2008) found that pretreatment with genistein attenuated $A \beta$-induced death of cortical neurons in vitro by lowering oxidative stress. It is plausible that genistein provides a protective effect via its anti-inflammatory influence, or via inhibition of the endoplasmic reticulum stress that arises due to accumulation of unfolded proteins (Park et al., 2010). Overall, it appears that genistein has a positive impact on various cellular mechanisms that are assumed to underlie the development of AD. Therefore, genistein may be a good candidate in the search for compounds that can be used to prevent or treat $\mathrm{AD}$ in the future. We have previously observed that genistein ameliorated impairment of short-term spatial memory induced by intrahippocampal injection of $A \beta_{1-40}$ in rats (Bagheri et al., 2011). In the current study, we addressed the question of whether injection of $\mathrm{A} \beta_{1-40}$ in the rat brain is associated with pathology in the hippocampus, and if genistein has any protective effect against the neuronal damage caused by $\mathrm{A} \beta_{1-40}$. 


\section{Results}

The cerebrum was mechanically damaged at the site of the needle insertion, and the surrounding tissue contained many small glia-like cells. Congo-red-stained brain sections showed no apple-green birefringence in a polarizing microscope, which suggests the lack of amyloid fibrils in the tissue. The slides that were incubated without primary antibodies and served as negative controls lacked any sign of immunoreactivity. These observations were made in sections from rats in all groups and are not further mentioned below.

\subsection{Sham-operated rats}

In hippocampal sections from these rats, cresyl-violet staining indicated normal morphology (Figure 1A1). The mean numbers ( \pm SEM) of cells were $149 \pm 6$ in CA1, $107 \pm 5$ in CA3, and $306 \pm 22$ in DGlb (Figures $2 \mathrm{~A}-\mathrm{C}$ ), and no $\mathrm{A} \beta$ immunoreactivity was observed in the tissue (Figure 1A2). The iNOS ${ }^{+}$(Figure 3A1) and $\mathrm{nNOS}^{+}$(Figure 3A2) cells were most common in $\mathrm{CA} 1, \mathrm{CA} 3$, and DG, and were rare in CA2 and stratum radiatum; cells in stratum oriens showed no immunoreactivity. For the mean number of iNOS ${ }^{+}$and $\mathrm{nNOS}^{+}$cells in the hippocampus see figures $4 \mathrm{~A}-\mathrm{B}$.

$\mathrm{GFAP}^{+}$astrocytes were observed throughout the cerebral cortex and hippocampus. Immunoreactivity was most intense in corpus callosum (CC) and the hippocampal strata cingulate and oriens, and DG polymorphic layer; less extensive in strata radiatum and molecular; and weakest in stratum lacunosum. In the cortex, immunoreactivity was greater in layers 5-6 than in superficial layers and was not detectable in stratum granular (Figure 1A3). The reactive astrocytes exhibited star-like morphology (Figure 1A4). The mean intensity of GFAP ${ }^{+}$ 

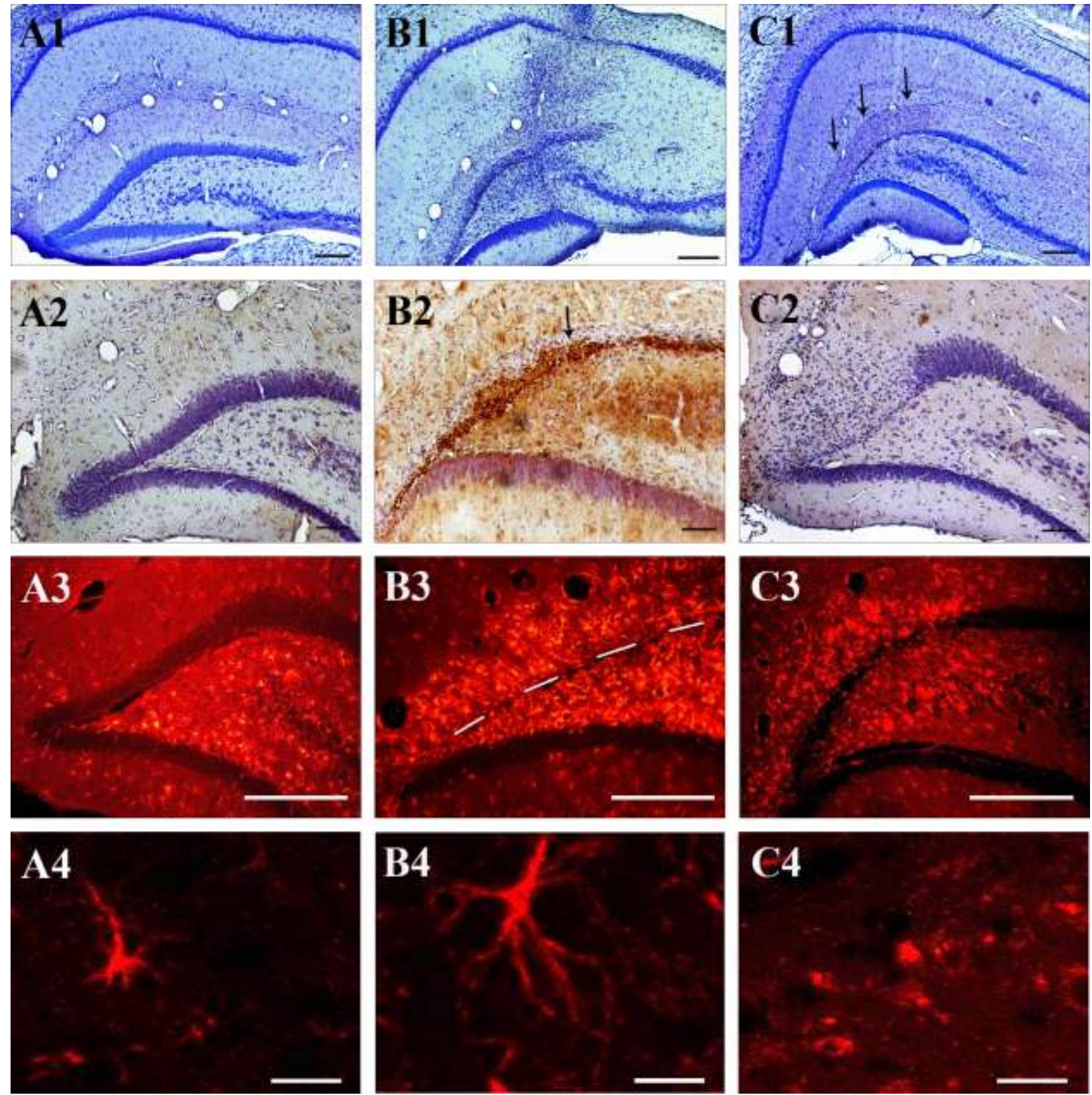

Figure 1. Micrographs of hippocampal sections stained with cresyl violet $(\mathrm{A} 1-\mathrm{C} 1)$ or with antibodies against $\mathrm{A} \beta_{1-}$ ${ }_{40}(\mathrm{~A} 2-\mathrm{C} 2)$ or GFAP (A3-C4). Sections from sham-operated rats (A1-A3) showed the following: normal morphology (A1), no $A \beta_{1-40}$ immunoreactivity (A2), and some GFAP ${ }^{+}$cells (A3). Injection of $A \beta_{1-40}(2 \mathrm{nM})$ into the hippocampus led to complete degeneration of neurons in DGlb (B1-B2), aggregation of A $\beta_{1-40}$ (B2; arrowheads), and intracellular expression of GFAP in a large area of the hippocampus (B3). Sections from genistein-treated (gavage, single dose of $10 \mathrm{mg} / \mathrm{kg}$ ) A $\beta_{1-40}$-injected rats showed partial degeneration in DGlb $(\mathrm{C} 1-\mathrm{C} 2)$, no $\mathrm{A} \beta_{1-40}$ immunoreactivity $(\mathrm{C} 2)$, and the $\mathrm{GFAP}^{+}$cells $(\mathrm{C} 3)$ exhibited morphology $(\mathrm{C} 4)$ that differed from that of cells in hippocampal sections from sham-operated (A4) and $\mathrm{A} \beta_{1-40}$-injected (B4) rats. Magnification: $\mathrm{x} 40$ (A1-C1); 100 (A2, C2); x 200 (B2, A3-C3); x 630 (A4-C4). 

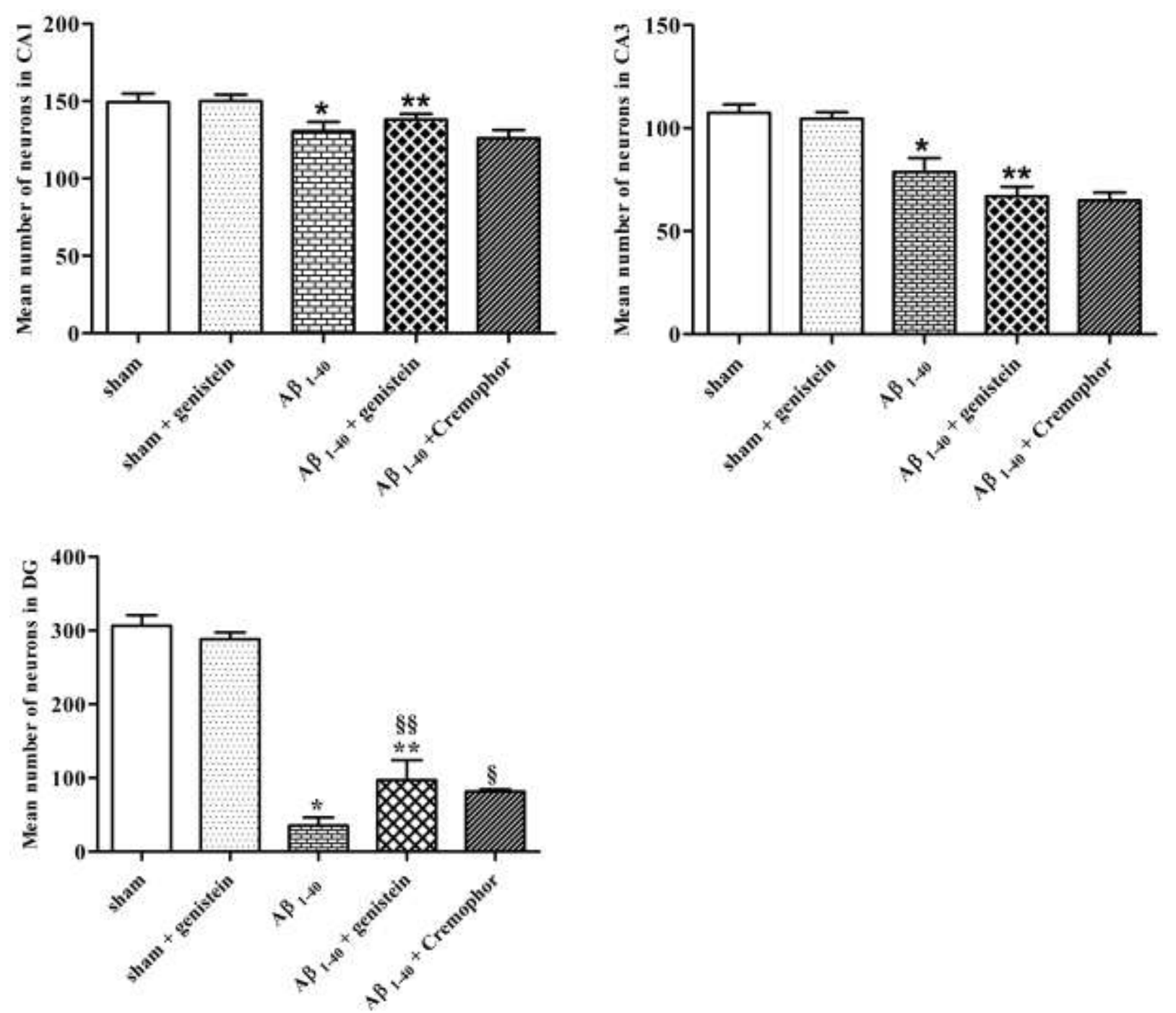

Figure 2. Mean numbers of neurons in subdivisions of hippocampus, counted in five sections/animal. Treatments: sham, normal saline was injected into hippocampus $(n=5)$; sham + genistein, genistein $\left(10 \mathrm{mg} / \mathrm{kg}\right.$ in $0.5 \mathrm{ml}$ of Cremophor $\left.{ }^{\circledR} \mathrm{EL}\right)$ was given by gavage before sham operation $(\mathrm{n}=5) ; A \beta_{1-40}$, the peptide $(2 \mathrm{nmol} / 4 \mu \mathrm{l})$ was injected into hippocampus $(\mathrm{n}=6) ; A \beta 1-$ $40^{+}$genistein, genistein was given before injection of the peptide $(n=6)$; A $\beta 1-40+$ Cremophor EL, Cremophor ${ }^{\circledR}$ EL was administered by gavage before injection of the peptide $(n=4)$. Values are means \pm SEM. Data are shown for the following hippocampal areas: CA1 (2A), $* P=0.03$ (vs. sham) and $* * P=0.03$ (vs. sham + genistein); CA3 (2B), ${ }^{*} P=0.002$ (vs. sham) and $* * P<$ 0.0001 (vs. sham + genistein); DGlb (2C), ${ }^{*} P<0.0001$ (vs. sham), ${ }^{*} * P<0.0001$ (vs. sham + genistein), $\S \S P=0.03$ (vs. $\mathrm{A} \beta_{1-40}$ ), and $\S P=0.02$ (vs. $\mathrm{A} \beta_{1-40}$ ). 

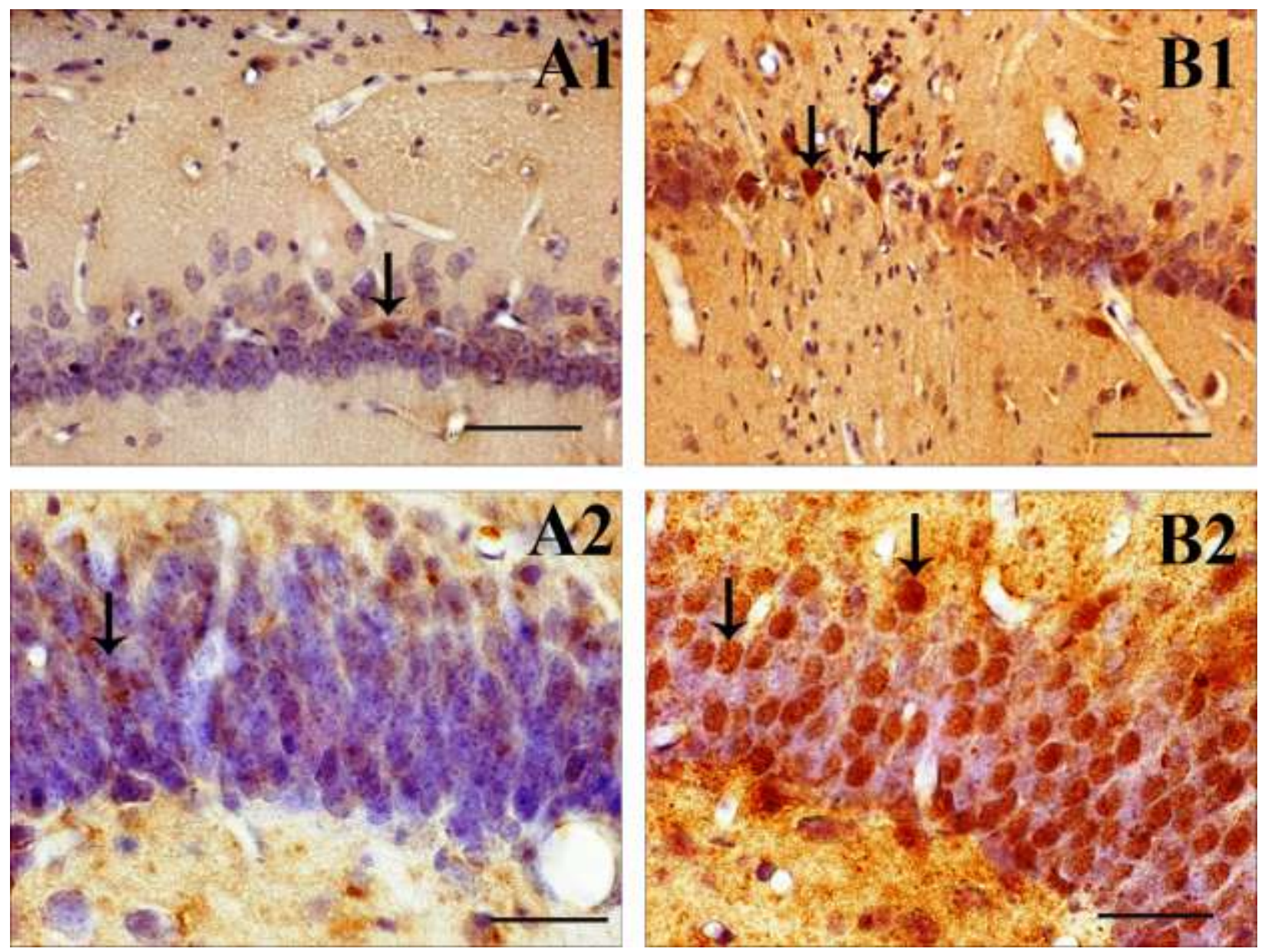

Figure 3. Micrographs showing iNOS (A1, B1) and nNOS (A2, B2) immunoreactive cells (arrows) in the hippocampus of sham-operated (A1, A2) and $A \beta_{1-40}$-injected (B1, B2) rats. CA1 is shown in A1 and B1, and DGmb in A2 and B2. Magnification: x400 (A1-B1); x600 (A2-B2).

immunoreactivity in the hippocampus measured by confocal microscope was $45.9 \pm 4.8$ (Figure 5).

\subsection{Sham-operated genistein-treated rats}

Compared with the sham-operated animals, the following was found for the sham-operated animals that were given genistein: normal morphology in cresyl violet staining, equivalent mean numbers of neurons/section (CA1, $150 \pm 4$; CA3, $105 \pm 3$; DGlb, $288 \pm 11$; Figures $2 \mathrm{~A}-\mathrm{C}$ ), and 
the same patterns of $\mathrm{A} \beta$, iNOS, nNOS, and GFAP immunoreactivity. For number of $\mathrm{iNOS}^{+}$and $\mathrm{nNOS}^{+}$cells in the hippocampus see figures $4 \mathrm{~A}-\mathrm{B}$.

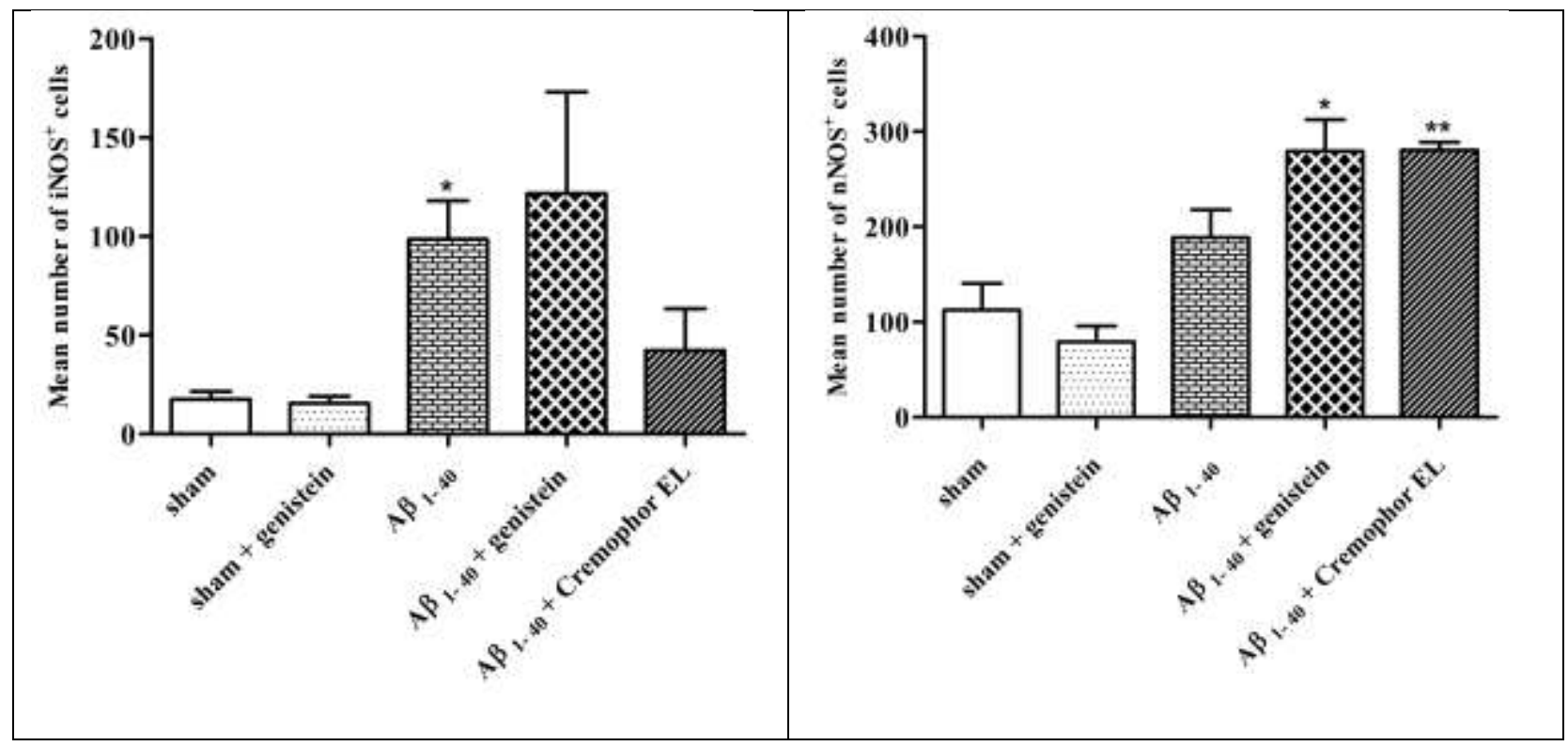

Figure 4. Number of iNOS (A) and nNOS (B) immunoreactive cells in the hippocampus counted in three sections/animal. Treatments: sham, normal saline was injected into the hippocampus (n = 5); sham + genistein, genistein $\left(10 \mathrm{mg} / \mathrm{kg}\right.$ in $0.5 \mathrm{ml}$ of Cremophor $\left.{ }^{\circledR} \mathrm{EL}\right)$ was given by gavage before sham operation $(\mathrm{n}=5) ; \mathrm{A} \beta_{1-40}$, the peptide $(2 \mathrm{nmol} / 4 \mu \mathrm{l})$ was injected into the hippocampus $(n=6) ; A \beta_{1-40}{ }^{+}$genistein, genistein was administered before injection of the peptide $(\mathrm{n}=6) ; \mathrm{A} \beta_{1-40}{ }^{+}$Cremophor EL, the vehicle was given by gavage before injection of the peptide $(\mathrm{n}=4)$. Values are means \pm SEM. iNOS,$+{ }^{*} P=0.01$ (vs. sham); $\mathrm{nNOS}+,{ }^{*} P=0.0001$ (vs. sham + genistein) and $* * P=0.01$ (vs. A $\left.\beta_{1-40}\right)$.

\subsection{Aß-injected rats}

Cresyl-violet-stained sections from the hippocampus of $A \beta$-injected rats differed from those obtained from sham-operated animals (Figure 1B1). A few cells with intracellular brown pigment were observed along the DGlb and CC, and these were also recognized in unstained sections due to their brownish appearance. Sections from five of the six rats had homogeneous extracellular pink material close to the DGlb (Figure 6A), and this material exhibited positive $\mathrm{A} \beta_{1-40}$ immunoreactivity (Figures 1B2 and 6B). The DGlb showed signs of extensive cell loss, which had developed mediolaterally and caused complete degeneration of this area in the five 
animals that exhibited A $\beta$-positive deposition. Furthermore, sparsely distributed pyramidal cells were seen in a short segment of the medial CA1. The numbers of neurons counted in CA1 (131 \pm 6; $P=0.03), \mathrm{CA} 3(79 \pm 7 ; P=0.002)$, and DGlb $(35 \pm 11 ; P<0.0001)$ were significantly lower than the numbers found in the corresponding areas in the sham-operated rats (Figure 2A-C).

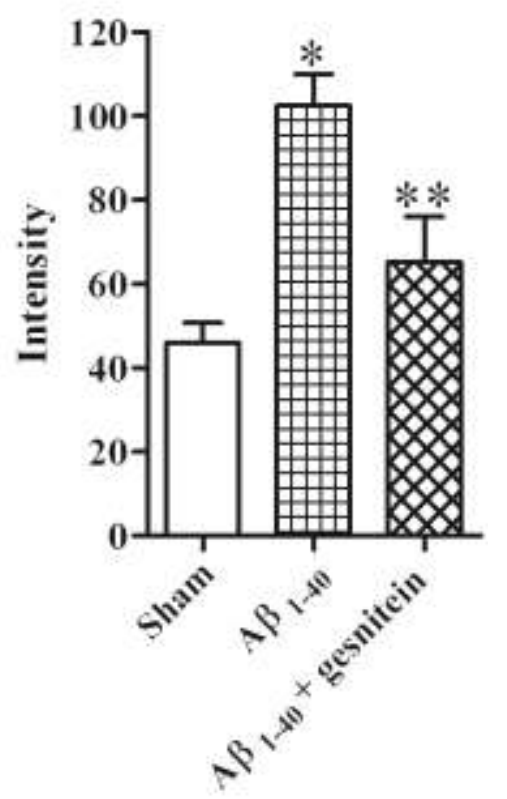

Figure 5. Mean intensity of GFAP positive immunoreactivity is shown in sham operated, $A \beta_{1-40}$ injected and A $\beta 1-40$ injected- genistein treated rats. Values are means \pm SEM. $* P=0.0006$ (sham vs. $\mathrm{A} \beta) ;{ }^{* *} P=0.02\left(\mathrm{~A} \beta_{1-40}\right.$ vs. $\mathrm{A} \beta_{1-40}+$ genistein)

The iNOS ${ }^{+}$(Figure 3B1) and $\mathrm{nNOS}^{+}$(Figure 3B2) neurons of the A $\beta$-injected rats showed more extensive intracellular immunoreactivity compared to those of the sham-operated animals. These cells occurred mostly in CA1, CA3, and medial blade of DG (DGmb), and rarely in CA2 and striatum radiatum. As can be seen, the DGlb was degenerated and hence prior iNOS and nNOS expressing neurons in this area was not known. There were also iNOS ${ }^{+}$cells in the cerebral cortex. The mean number of iNOS ${ }^{+}$cells $(P=0.01$; Figure $4 \mathrm{~A})$ was significantly increased in the hippocampus of $\mathrm{A} \beta$-injected rats. The number of $\mathrm{nNOS}^{+}$cells was also raised but due to 
disappearance of the neurons in the DGlb this number did not reach a significance level (Figure 4B).
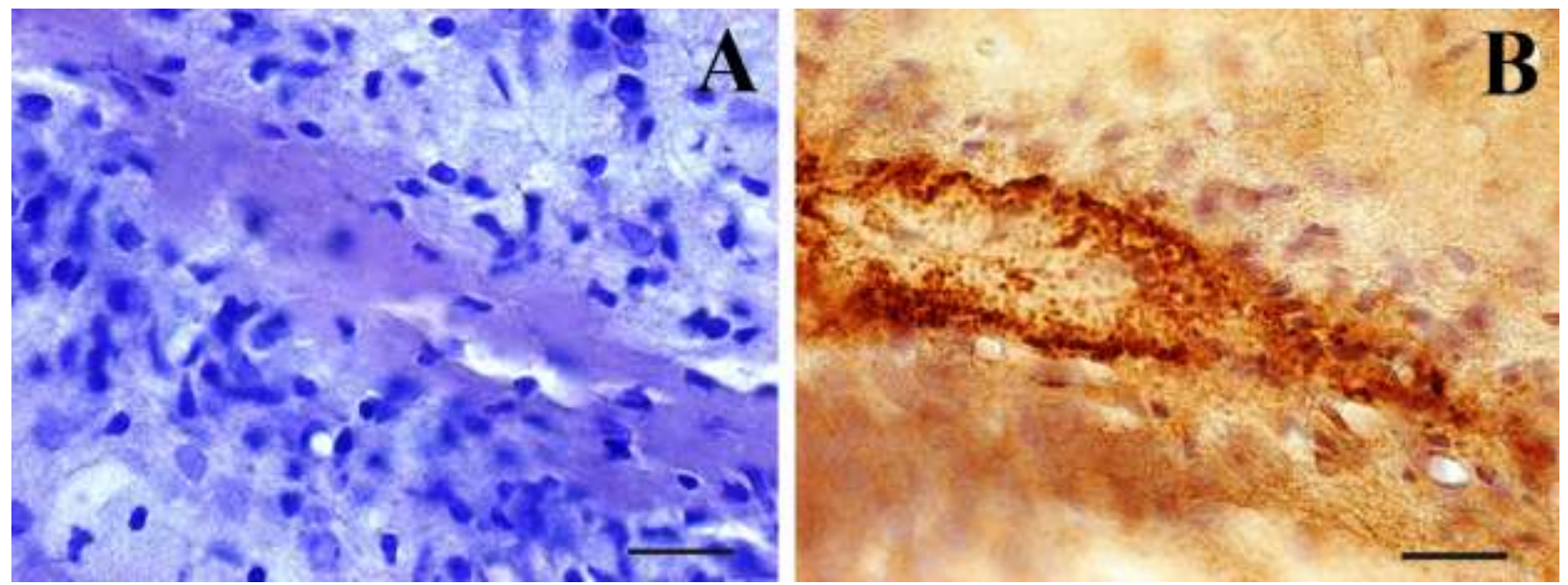

Figure 6. Homogeneous pink matrix after cresyl violet staining (A) and positive immunoreactivity to $A \beta_{1-40}$ antibodies (B) in DGlb of rats injected with $A \beta_{1-40}$ in hippocampus.

The A $\beta$-injected rats also had extensive signs of GFAP overexpression as a sign of astrogliosis in the hippocampus. The GFAP ${ }^{+}$cells were densely packed in the area between the DGlb and DGmb (Figure 1B3), in stratum moleculare, and in the degenerated granular layer of the DGlb. These reactive astrocytes exhibited star-like features with a dense network of finely branching and sometimes overlapping processes (Figure 1B4). Compared with sham-operated rats, the mean intensity of GFAP immunoreactivity was significantly increased in the hippocampus $(102.3 \pm 7.5 ; P=0.0006 ;$ Figure 5$)$. The distribution of the immunoreactivity, however, differed between different areas. We observed less $\mathrm{GFAP}^{+}$immunoreactivity in strata radiatum, oriens and the deep layers of the cerebral cortex, and there was no immunoreactivity in the CC and cingulum while it was extensively expressed in the molecular, granular and polymorphic layers.

\subsection{Aß-injected genistein-treated rats}


The microscopic picture of the brain varied considerably in the $A \beta$-injected genistein-treated rats. The DGlb had a few cell-like structure with intracellular brown pigment in all animals, appeared completely normal in two, showed segmental degeneration in one (Figure 1C1), and was completely degenerated in three. Numerous small glia-like cells were visible in the sections exhibiting neuronal degeneration in the DGlb. In cresyl-violet-stained sections, stratum molecular had a more intensive pink colour in part of the tissue parallel to the degenerated DGlb (Figure 1C1, arrows). The hippocampal sections showed no homogeneous extracellular pink material similar to that we observed in $A \beta_{1-40}$ animals, and had no $\mathrm{A} \beta_{1-40}$ immunoreactive cells or aggregates (Figure 1C2). The mean numbers of cells in the CA1 (138 $\pm 4 ; P=0.03)$, CA3 (67 $\pm 5 ; P<0.0001)$ and DGlb $(97 \pm 15 ; P<0.0001)$ were significantly lower compared with corresponding areas in the sham-operated genistein-treated rats (Figure $2 \mathrm{~A}-\mathrm{C}$ ). Compared to the $\mathrm{A} \beta_{1-40}$-injected animals, however, genistein treatment significantly improved the rate of cell survival in the DGlb $(P=0.03$; Figure $2 \mathrm{C})$.

The A $\beta$-injected genistein-treated animals displayed the same pattern of distribution of iNOS ${ }^{+}$ and $\mathrm{nNOS}^{+}$cells as seen in the animals subjected only to $\mathrm{A} \beta$ injection. Moreover, they showed an increased number of $\mathrm{nNOS}^{+}\left(P=0.0001\right.$; Figure 4B) but not iNOS ${ }^{+}$(Figure 4A) cells compared with the sham-operated genistein-treated rats. Astrogliosis occurred in an area around the degenerated DGlb in a similar pattern as observed in the animals with $\mathrm{A} \beta$ injection only. This intensive GFAP immunoreactivity sharply declined where the DGlb appeared normal (Figure 1C3). Furthermore, the polymorphic and granular cell layers of the $A \beta$-injected genistein-treated DG showed less astrogliosis compared to what was seen after exposure to $A \beta_{1-40}$ only. Also in contrast to the $\mathrm{A} \beta$-only animals, the $\mathrm{A} \beta$-genistein-treated rats showed $\mathrm{GFAP}^{+}$astrocytes that 
were extensively packed together and lacked $\mathrm{GFAP}^{+}$branches in some regions. The mean intensity of GFAP immunoreactivity was decreased significantly in comparison with $\mathrm{A} \beta$-injected rats $(65.34 \pm 10.72 ; P<0.02$; Figure 5$)$ and was similar to the intensity measured in the hippocampus of the sham-operated rats.

\subsection{Aß-injected Cremophor-treated rats}

Microscopy of the cresyl-violet-stained brain sections of these rats revealed diversity similar to that observed in the $A \beta_{1-40}$-injected genistein-treated animals: the hippocampus appeared normal (one rat) or showed segmental (two rats) or complete (one rat) degeneration of the DGlb. Compared with the animals given only $\mathrm{A} \beta_{1-40}$, the $\mathrm{A} \beta-/$ CremophorEL (CrEL)-treated rats were found to have similar numbers of neurons in CA1 (126 \pm 3$)$ and CA3 (62 \pm 3$)$, but a significantly larger number in the $\mathrm{DGlb}(78 \pm 3 ; P=0.02)$. Furthermore, they showed the same pattern of distribution of $\mathrm{iNOS}^{+}$and $\mathrm{nNOS}^{+}$cells, however, the mean number of $\mathrm{nNOS}^{+}$cells was significantly increased $(P=0.01$; Figure 4B).

The pattern of gliosis in the brains of the animals exhibiting DGlb neuronal degeneration was similar to that observed in the $\mathrm{A} \beta$-only rats with densely $\mathrm{GFAP}^{+}$network. In contrast to $\mathrm{A} \beta_{1-40}$ injected genistein treated animals, the microscopic examination of the hippocampus of these rats

revealed occurrence of $\mathrm{A} \beta_{1-40}{ }^{+}$aggregates, and extensive astrogliosis in the hippocampus similar to the $A \beta$-injected animals. 


\section{Discussion}

The present study was performed to examine whether intrahippocampal injection of $A \beta_{1-40}$ is associated with pathology in the hippocampus and if genistein has any protective effect against the neuronal damage cause by the peptide. We found extensive neuronal degeneration, $A \beta_{1-40}$ positive aggregates and astrogliosis in the hippocampus of $\mathrm{A} \beta_{1-40}$ injected rats. Genistein treatment inhibited formation of $\mathrm{A} \beta_{1-40}$ positive aggregates and ameliorated astrogliosis.

\subsection{Intrahippocampal injection of $A_{1-40}$ causes neuronal degeneration in the DGlb}

In the current study, injection of $A \beta_{1-40}$ into the rat brain caused extensive neuronal degeneration in the DGlb. However, other researchers have obtained contradictory results after injecting the peptide to achieve such interference; in short, some have demonstrated neuronal degeneration (Miguel-Hidalgo et al., 2002), whereas others have found no signs of pathology (Games et al., 1992). The toxicity of $A \beta$ can be influenced by variables involved in preparation of the peptide (Busciglio et al., 1992). For example, a freshly prepared solution of $A \beta$ can be less toxic than a solution that has been incubated for hours at a temperature higher than $20{ }^{\circ} \mathrm{C}$, because the $\mathrm{A} \beta$ is in monomer form in the former but creates neurotoxic fibrils in the latter (Kim et al., 2003). Han and colleagues (Han et al., 2011), for example, incubated $A \beta_{1-40}$ in $37^{\circ} \mathrm{C}$ for one week and injected the aggregates of the peptide in the brain; they observed neuronal degeneration in the hippocampus 14 days after injection. We injected $A \beta$ solution within 30 min to $4 \mathrm{~h}$ of preparation, and hence it is likely that the peptide was primarily in monomer form. The lack of fibrils is further supported by the absence of apple-green birefringence in Congo-red-stained sections under polarized light. This finding indicates that even non-fibrillar form of $\mathrm{A} \beta$ has neurotoxic properties, as has been suggested by other investigators (Kim et al., 2003). The dose 
of $A \beta$ or the time interval between injection of the peptide and perfusion of animals can also affect the pathological outcome. Ren and colleagues (Ren et al., 2011) injected $10 \mu \mathrm{g}$ of $\mathrm{A} \beta_{25-35}$ into the hippocampus of rats and observed ultrastructural signs of cell death after 21 days, whereas slight mitochondrial changes were the only sign of pathology after 14 days of such treatment or after injection of smaller amount of the peptide. Furthermore, Piermartiri and colleagues (Piermartiri et al., 2010) injected $\mathrm{A} \beta_{1-40}$ in the mice brain and did not observe any alteration in cellular viability 9 days after injection. At 16 th day, however, $A \beta_{1-40}$ infusion caused increased cell degeneration in the hippocampus. The rats in our study were sacrificed 3 weeks after $A \beta$ injection, and during that period the neuronal death had involved the whole DGlb.

Harris and co-workers (Harris et al., 2010) used transgenic mice overexpressing APP/A $\beta$ in neurons of the entorhinal cortex and found that the toxicity of the peptide was propagated from that cortex to the hippocampus. By comparison, we injected $\mathrm{A} \beta$ into the $\mathrm{CA} 1$ region, but cell degeneration affected neurons in DGlb. In vitro, $A \beta_{1-40}$ activated the apoptotic pathway in hippocampal neurons after $24 \mathrm{~h}$, whereas cortical neurons were affected after $48 \mathrm{~h}$; hippocampal neurons were also vulnerable to lower concentration of the peptide (Resende et al., 2007). Furthermore, the $\mathrm{CA} 1$ region of the hippocampus is more vulnerable than the $\mathrm{CA} 3$ region in $\mathrm{AD}$ patients (Kim et al., 2003). This clearly shows that the vulnerability of neurons exposed to A $\beta$ differs in different regions of the brain.

Song and colleagues (Song et al., 2011) recently reported that cortical neurons internalize exogenous $A \beta$ in a dose- and time-dependent manner, and this leads to neuronal degeneration, possibly due to activation of the endosomal-lysosomal system. Moreover, Cuevas and colleagues 
(Cuevas et al., 2011) suggested that intrahippocampal injection of $A \beta$ increases expression of the receptor for advanced glycation end products (RAGE), which leads to events such as enhanced production of pro-apoptotic factors and NO. The pathological effects of $\beta$-amyloid are associated with other events such as the following: increased synaptic transmission (Cuevas et al., 2011), imbalance between elevated levels of inflammatory cytokines and decreased levels of neurotrophic factors in the brain tissue (Ji et al., 2011), and mitochondrial dysfunction (Ren et al., 2011; Tillement et al., 2011). Together, these findings show that $\beta$-amyloid triggers a cascade of extra- and intracellular events, all of which may be involved in neuronal degeneration. The question that remains is what event occurs first, and how activation of that particular event can be inhibited.

\subsection{Effect of genistein on formation of Aß aggregates and neurodegeneration}

In our experiments, the most significant effect of genistein was that it prevented formation of $\mathrm{A} \beta$-containing aggregates. In addition, neurons in a part of the DGlb were preserved after genistein treatment, which seems to underline our previous finding that this isoflavone alleviated learning and memory deficits in A $\beta$-injected rats (Bagheri et al., 2011). It should be emphasized that such improved cell survival, but not inhibition of $A \beta$ aggregation, was also observed after treatment with CrEL (the vehicle of genistein). However, the mechanism by which CrEL improves the ability of neurons to resist $\mathrm{A} \beta$ is unknown. $\mathrm{CrEL}$, used as a solvent for hydrophobic

drugs, is associated with axonal damage in the peripheral nerves (Gelderblom et al., 2001), it has an antinociceptive effect (Tabarelli et al., 2003), and it limits the absorption of drugs in the gastrointestinal canal (Malingre et al., 2001). These observations show that the vehicle of drugs may have biological effects that influence the development of the pathology and, therefore, their effect should be considered before making any conclusion. According to the results of the 
present study, the vehicle of genistein may have played a role in the neuroprotective effect of this substance. Genistein can be dissolved in different solvents such as olive oil, ethanol, dimethyl sulfoxide (DMSO), sesame oil and propylene glycol. Ding and colleagues (2011) treated A $\beta_{31-35}$ exposed cortical neurons with genistein that was dissolved in DMSO and observed increased cell viability and reduced concentration of $\mathrm{Ca}^{2+}$ and reactive oxygen species (ROS) (Ding et al., 2011). In our previous study on the neuroprotective effect of genistein in a rat model of Parkinson disease we used propylene glycol as solvent for genistein and found improved cell survival and attenuated rotational behavior after genistein treatment in these animals (Baluchnejadmojarad et al., 2009). Together, these data also suggest that genistein itself can, in some degree, protect neurons against harmful agents irrespective of the solvent used.

\section{3 iNOS, nNOS and astrogliosis}

Nitric oxide (NO) is an important source of ROS and reactive nitrogen species (RNS), such as $\mathrm{O}_{2}^{-}$and $\mathrm{ONOO}^{-}$. NO is synthesized by the enzyme NO synthase (NOS), which exists in three isoforms that are called neuronal, inducible, and endothelial NOS (nNOS, iNOS, and eNOS). NO can induce neurotransmitter release from hippocampal slices (Lonart et al., 1992) and plays a role in regulating the hippocampal synaptic plasticity (Calabrese et al., 2007). NO converts thiol groups in proteins to form S-nitrosothiols through what is called S-nitrosylation. This process can inhibit activation of caspases (Liu and Stamler, 1999; Melino et al., 1997), and it reduces intracellular influx of $\mathrm{Ca}^{2+}$ by exerting its effect on NMDA receptors (Calabrese et al., 2007). NO can also induce hippocampal cells to produce heme oxygenase 1 , which reduces biliverdin to bilirubin, a pigment that has antioxidant and anti-nitrosative effects. During inflammation, NO is produced by cytokine-induced NOS and plays a harmful role by producing oxidative agents. Expression of NOS increases in various neurodegenerative diseases, and some scientists believe 
that this augments the neurodegenerative events (Calabrese et al., 2007), although other investigators have suggested that the cell death is due to a lack of NOS (Gargiulo et al., 2000; Hyman et al., 1992). We found that injection of $A \beta$ into the hippocampus increased the intracellular expression of nNOS, but did not raise the number of nNOS-expressing cells due to extensive degeneration of neurons in the DGlb. This finding is similar to results obtained by others after intracerebroventricular injection of $A \beta_{25-35}$ (Stepanichev et al., 2008). On the other hand, Li and colleagues ( $\mathrm{Li}$ et al., 2004) observed loss of nNOS-containing neurons after intrahippocampal injection of $A \beta_{1-40}$. This discrepancy may be explained by differences in the degree of $\mathrm{A} \beta$ toxicity and neuronal degeneration or cell counting methods used in different studies. By comparison, in our experiments the DGlb was completely degenerated in A $\beta$-injected rats, which reduced the population of nNOS-expressing neurons. In the current study, genistein significantly increased the expression and the number of nNOS expressing cells. The same effect was also observed in $\mathrm{A} \beta_{1-40}$ injected CrEL treated animals. This pattern of nNOS expression was due to the presence of more neurons in the DGlb in these groups compared to those receiving only $A \beta_{1-40}$. Furthermore, the similar pattern of nNOS expression that was observed in the $A \beta_{1-40}$ injected CrEL treated and the $A \beta_{1-40}$ injected genistein treated animals also indicate that there was no direct relation between the presence of $A \beta_{1-40}$ immunoreactive aggregates and nNOS expression since these aggregates were present in the former but not the latter group.

We also found that expression of iNOS and the number of cells expressing this enzyme was increased in the hippocampus after exposure to $A \beta_{1-40}$. According to previous studies, iNOS expression rises in both glial and nerve cells after exposure to A $\beta$ (Valles et al., 2010), haemolysate (Lu et al., 2009), or various inflammatory agents (Moncada et al., 1991; Yun et al., 
1997), and genistein treatment prevents iNOS expression (Lu et al., 2009; Valles et al., 2010). In our investigation, genistein treatment did not block either the increased iNOS expression or the number of iNOS expressing cells in the hippocampus, and hence it is possible that a chronic treatment is necessary to achieve that goal. Furthermore, the pattern of iNOS expression was similar in the $A \beta$ injected rats with or without genistein treatment although the former group, but not the latter group, exhibited the accumulation of $A \beta$ immunoreactive aggregates. This observation indicates that the aggregates did not affect the expression of iNOS.

Astrocytes respond to damage by initiating astrogliosis, which entails abnormal increase in the number of these cells (Rodriguez et al., 2009; Sofroniew and Vinters, 2010). Astrogliosis and glial scar formation are suggested to act as a neuroprotective barrier against harmful agents (Pekny et al., 1995). Astrocytes occur in close association with amyloid plaques and they can take up and degrade extracellular amyloid (Wyss-Coray et al., 2003). Furthermore, colocalization of $A \beta$ immunoreactive extracellular matrix and GFAP immunoreactivity was recently reported by Perez and colleagues (Perez et al., 2010) after injection of $A \beta_{1-40}$ in rat brain. Our results indicate that astrogliosis occurs in association with neurodegeneration irrespective of presence or absence of extracellular $A \beta$ aggregates. Furthermore, our results suggest that genistein treatment alleviated the gliosis as evaluated by intensity of GFAP immunoreactivity. The mechanism underlying this effect of genistein is not known. According to previous data, however, inflammation-inducing agents such as $\mathrm{A} \beta$ trigger NF- $\mathrm{kB}$ activation in astrocytes (Gonzalez-Velasquez et al., 2011) leading to inflammatory response, and this activation can be inhibited by genistein (Hsieh et al., 2011). 
In conclusion, our findings suggest that genistein treatment can inhibit formation of $A \beta$ deposits and limits astrogliosis caused by injection of $A \beta_{1-40}$ in the hippocampus. 


\section{Experimental procedure}

This study was carried out in accordance with the policies set forth in the Guide for the Care and Use of Laboratory Animals (NIH) and those stipulated by the Research Council of Tehran University of Medical Sciences (Tehran, Iran). The chemicals used were purchased from SigmaAldrich (USA), unless otherwise indicated. All qualitative and quantitative evaluations were performed on coded slides.

\subsection{Preparation of $A \beta_{1-40}$ and genistein}

$\mathrm{A} \beta_{1-40}$ (product no. 7973) was dissolved in $0.9 \%$ normal saline $(\mathrm{pH} 8.0 ; 0.5 \mathrm{nM} / \mu \mathrm{l})$ and stored at $-70{ }^{\circ} \mathrm{C}$. The solution was thawed on ice before injection into the hippocampus. Genistein (10 $\mathrm{mg} / \mathrm{kg}$ ) was dissolved in $0.5 \mathrm{ml}$ of CrEL.

\subsection{Animals}

Adult male Wistar rats (250-300 g) were randomly assigned to five groups: (A) sham operation $(\mathrm{n}=5) ;(B)$ sham operation and genistein treatment $(\mathrm{n}=5) ;(C) A \beta_{1-40}$ injection $(\mathrm{n}=6) ;(\mathrm{D})$ $\mathrm{A} \beta_{1-40}$ injection and genistein treatment $(\mathrm{n}=6) ;(\mathrm{E}) \mathrm{A} \beta_{1-40}$ injection and CrEL (vehicle) treatment $(n=4)$. The rats in groups A and B served as controls for groups C and D, respectively; rats in group E served as controls for group D. Genistein and CrEL were administered orally by gavage one hour before injection of $A \beta_{1-40}$.

\subsection{Surgery}

Rats were anaesthetized by intraperitoneal injection of ketamine $(100 \mathrm{mg} / \mathrm{kg})$ and xylazine (10 $\mathrm{mg} / \mathrm{kg}$ ), and then placed on a stereotaxic instrument (Stoelting, USA) and given $4 \mu \mathrm{l}$ of normal saline (groups $\mathrm{A}$ and $\mathrm{B}$ ) or $\mathrm{A} \beta_{1-40}(2 \mathrm{nM}$; groups $\mathrm{C}-\mathrm{E})$ bilaterally in the hippocampus at $-3.5 \mathrm{~mm}$ 
posterior to bregma, $\pm 2 \mathrm{~mm}$ lateral to midline, and $-2.8 \mathrm{~mm}$ below dura, according to the stereotactic atlas of Paxinos and Watson (Paxinos and Watson, 1998). Injections were performed over $4 \min (1 \mu \mathrm{l} / \mathrm{min})$ in each hemisphere using a Hamilton syringe with a $26 \mathrm{~S}$ gauge needle. The needle was left in place for an additional 5 min and thereafter slowly retracted.

\subsection{Specimen preparation and histochemistry}

Three weeks after the surgery, animals were anesthetized (ketamine, $150 \mathrm{mg} / \mathrm{kg}$ ) and perfused with $4 \%$ paraformaldehyde in $0.1 \mathrm{M}$ PBS (pH 7.4). After post-fixation of the brain, the left

hemispheres were embedded in paraffin; the hippocampus was cut in $20-\mu \mathrm{m}$ coronal sections and prepared for cresyl-violet and Congo red staining. In a microscope (Zeiss, Germany; $400 \mathrm{x}$, microscopic field diameter $440 \mu \mathrm{m}$ ), the number of hippocampal neurons was counted in every sixth cresyl-violet-stained section in CA1 (four fields), CA3 (two fields), and the whole lateral blade (lb) of the dentate gyrus (DG) in a mediolateral direction. Cells with a clear membrane, and a visible nucleolus were counted in five sections from each animal; this was done to determine the relative change in number of neurons in the experimental rats compared to controls.

\subsection{Immunohistochemistry}

Sections were incubated at $4{ }^{\circ} \mathrm{C}$ overnight with rabbit antibodies against $\mathrm{A} \beta_{1-40}(1: 250)$, iNOS (1:100; ab cam), and nNOS (1:250; ab cam) diluted in PBS containing 3.5\% normal serum, $0.25 \%$ BSA, and $0.25 \%$ Triton X-100. Thereafter, the sections were rinsed in PBS, incubated for $45 \mathrm{~min}$ in $3 \% \mathrm{H} 2 \mathrm{O} 2$, washed in PBS, and then incubated at room temperature for $1 \mathrm{~h}$ with antirabbit IgG antibodies (1:200; ab cam). The sections were subsequently washed, incubated for 10 min in $3^{\prime}-3^{\prime}$-diaminobenzidine tetrahydrochloride (DAB), and stained with haematoxylin. The 
iNOS- and nNOS-positive cells in the hippocampus were counted in three sections from each animal.

Sections used for detection of reactive astrocytes were incubated for 5 min with serum-free protein block (Dako, Denmark) and with polyclonal rabbit antibodies against GFAP at $4{ }^{\circ} \mathrm{C}$ overnight (1:1500; Dako, Denmark, product code 0809). After washing, the sections were incubated for $1 \mathrm{~h}$ at room temperature with alkaline phosphatase-conjugated swine anti-rabbit IgG antibodies (1:100) and then for 15 min with liquid permanent red chromogen (Dako, Denmark) diluted in liquid permanent red substrate buffer. Negative controls were omitted from primary antibodies.

\subsection{Image analysis of GFAP intensity}

GFAP stained sections were viewed with an Olympus Zeiss confocal microscope. Images were acquired by digital camera with x 100 magnification. Total intensity of GFAP immunoreactivity was measured in two sections for each animal in a well-defined hippocampal area (1.1- 1.2 $\left.\mathrm{mm}^{2}\right)$.

\subsection{Statistical analysis}

All results were expressed as mean \pm SEM. Parametric one-way ANOVA was used to assess the differences between the numbers of cresyl-violet stained neurons in different groups. Due to large inter-group variation, Welch analysis was used to calculate the differences in the number of

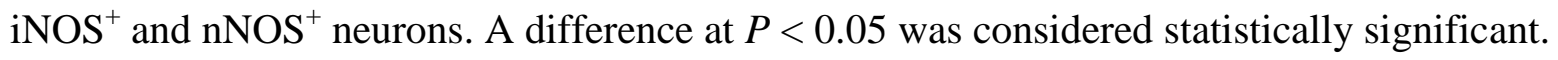





\section{Acknowledgements}

This work was financially supported by grants from the Cellular and Molecular Research Center at Tehran University of Medical Sciences (Tehran), Linköping University (Linköping, Sweden) and the County Council of Östergötland.

\section{Conflict of interest}

None of the authors has any conflict of interest. MR, MTJ, SM designed the study; MB, SM, carried out experiments; MB, SM, MR, Performed data analysis and interpretation of data; MB, SM, edited the manuscript and created the figures. 


\section{References}

Akiyama, T., Ishida, J., Nakagawa, S., Ogawara, H., Watanabe, S., Itoh, N., Shibuya, M., Fukami, Y., 1987. Genistein, a specific inhibitor of tyrosine-specific protein kinases. J Biol Chem. 262, 5592-5.

Bagheri, M., Joghataei, M.T., Mohseni, S., Roghani, M., 2011. Genistein ameliorates learning and memory deficits in amyloid beta(1-40) rat model of Alzheimer's disease. Neurobiol Learn Mem. 95, 270-6.

Baluchnejadmojarad, T., Roghani, M., Nadoushan, M.R., Bagheri, M., 2009. Neuroprotective effect of genistein in 6-hydroxydopamine hemi-parkinsonian rat model. Phytother Res. 23, 132-5.

Bang, O.Y., Hong, H.S., Kim, D.H., Kim, H., Boo, J.H., Huh, K., Mook-Jung, I., 2004. Neuroprotective effect of genistein against beta amyloid-induced neurotoxicity. Neurobiol Dis. 16, 21-8.

Borras, C., Gambini, J., Gomez-Cabrera, M.C., Sastre, J., Pallardo, F.V., Mann, G.E., Vina, J., 2006. Genistein, a soy isoflavone, up-regulates expression of antioxidant genes: involvement of estrogen receptors, ERK1/2, and NFkappaB. Faseb J. 20, 2136-8.

Busciglio, J., Lorenzo, A., Yankner, B.A., 1992. Methodological variables in the assessment of beta amyloid neurotoxicity. Neurobiol Aging. 13, 609-12.

Calabrese, V., Mancuso, C., Calvani, M., Rizzarelli, E., Butterfield, D.A., Stella, A.M., 2007. Nitric oxide in the central nervous system: neuroprotection versus neurotoxicity. Nat Rev Neurosci. 8, 766-75.

Cuevas, E., Lantz, S.M., Tobon-Velasco, J.C., Newport, G.D., Wu, Q., Virmani, A., Ali, S.F., Santamaria, A., 2011. On the in vivo early toxic properties of A-beta 25-35 peptide in the rat hippocampus: involvement of the Receptor-for-Advanced Glycation-End-Products and changes in gene expression. Neurotoxicol Teratol. 33, 288-96.

Ding, B., Yuan, L., Yu, H., Li, L., Ma, W., Bi, Y., Feng, J., Xiao, R., 2011. Genistein and folic acid prevent oxidative injury induced by beta-amyloid peptide. Basic Clin Pharmacol Toxicol. 108, 333-40.

Fratiglioni, L., Mangialasche, F., Qiu, C., 2010. Brain aging: lessons from community studies. Nutr Rev. 68 Suppl 2, S119-27.

Games, D., Khan, K.M., Soriano, F.G., Keim, P.S., Davis, D.L., Bryant, K., Lieberburg, I., 1992. Lack of Alzheimer pathology after beta-amyloid protein injections in rat brain. Neurobiol Aging. 13, 56976.

Games, D., Adams, D., Alessandrini, R., Barbour, R., Berthelette, P., Blackwell, C., Carr, T., Clemens, J., Donaldson, T., Gillespie, F., et al., 1995. Alzheimer-type neuropathology in transgenic mice overexpressing V717F beta-amyloid precursor protein. Nature. 373, 523-7.

Gargiulo, L., Bermejo, M., Liras, A., 2000. [Reduced neuronal nitric oxide synthetase and c-protein kinase levels in Alzheimer's disease]. Rev Neurol. 30, 301-3.

Gelderblom, H., Verweij, J., Nooter, K., Sparreboom, A., 2001. Cremophor EL: the drawbacks and advantages of vehicle selection for drug formulation. Eur J Cancer. 37, 1590-8.

Gonzalez-Velasquez, F.J., Reed, J.W., Fuseler, J.W., Matherly, E.E., Kotarek, J.A., Soto-Ortega, D.D., Moss, M.A., 2011. Activation of brain endothelium by soluble aggregates of the amyloid-beta protein involves nuclear factor-kappaB. Curr Alzheimer Res. 8, 81-94.

Han, M., Liu, Y., Tan, Q., Zhang, B., Wang, W., Liu, J., Zhang, X.J., Wang, Y.Y., Zhang, J.M., 2011.

Therapeutic efficacy of stemazole in a beta-amyloid injection rat model of Alzheimer's disease. Eur J Pharmacol. 657, 104-10.

Harris, J.A., Devidze, N., Verret, L., Ho, K., Halabisky, B., Thwin, M.T., Kim, D., Hamto, P., Lo, I., Yu, G.Q., Palop, J.J., Masliah, E., Mucke, L., 2010. Transsynaptic progression of amyloid-beta-induced neuronal dysfunction within the entorhinal-hippocampal network. Neuron. 68, 428-41.

Horiuchi, M., Maezawa, I., Itoh, A., Wakayama, K., Jin, L.W., Itoh, T., Decarli, C., 2010. Amyloid beta1-42 oligomer inhibits myelin sheet formation in vitro. Neurobiol Aging. 
Hsieh, H.M., Wu, W.M., Hu, M.L., 2011. Genistein attenuates D-galactose-induced oxidative damage through decreased reactive oxygen species and NF-kappaB binding activity in neuronal PC12 cells. Life Sci. 88, 82-8.

Huang, Y.H., Zhang, Q.H., 2010. Genistein reduced the neural apoptosis in the brain of ovariectomised rats by modulating mitochondrial oxidative stress. Br J Nutr. 104, 1297-303.

Hyman, B.T., Marzloff, K., Wenniger, J.J., Dawson, T.M., Bredt, D.S., Snyder, S.H., 1992. Relative sparing of nitric oxide synthase-containing neurons in the hippocampal formation in Alzheimer's disease. Ann Neurol. 32, 818-20.

Ji, C., Song, C., Zuo, P., 2011. The mechanism of memory impairment induced by abeta chronic administration involves imbalance between cytokines and neurotrophins in the rat hippocampus. Curr Alzheimer Res. 8, 410-20.

Kim, H.J., Chae, S.C., Lee, D.K., Chromy, B., Lee, S.C., Park, Y.C., Klein, W.L., Krafft, G.A., Hong, S.T., 2003. Selective neuronal degeneration induced by soluble oligomeric amyloid beta protein. Faseb J. $17,118-20$.

Lephart, E.D., Setchell, K.D., Handa, R.J., Lund, T.D., 2004. Behavioral effects of endocrine-disrupting substances: phytoestrogens. Ilar J. 45, 443-54.

Li, L.X., Dai, J.P., Ru, L.Q., Yin, G.F., Zhao, B., 2004. Effects of tanshinone on neuropathological changes induced by amyloid beta-peptide(1-40) injection in rat hippocampus. Acta Pharmacol Sin. 25, 861-8.

Liu, L., Stamler, J.S., 1999. NO: an inhibitor of cell death. Cell Death Differ. 6, 937-42.

Lonart, G., Wang, J., Johnson, K.M., 1992. Nitric oxide induces neurotransmitter release from hippocampal slices. Eur J Pharmacol. 220, 271-2.

Lu, H., Shi, J.X., Zhang, D.M., Wang, H.D., Hang, C.H., Chen, H.L., Yin, H.X., 2009. Inhibition of hemolysate-induced iNOS and COX-2 expression by genistein through suppression of NF-small ka, CyrillicB activation in primary astrocytes. J Neurol Sci. 278, 91-5.

Malingre, M.M., Schellens, J.H., Van Tellingen, O., Ouwehand, M., Bardelmeijer, H.A., Rosing, H., Koopman, F.J., Schot, M.E., Ten Bokkel Huinink, W.W., Beijnen, J.H., 2001. The co-solvent Cremophor EL limits absorption of orally administered paclitaxel in cancer patients. Br J Cancer. 85, 1472-7.

Melino, G., Bernassola, F., Knight, R.A., Corasaniti, M.T., Nistico, G., Finazzi-Agro, A., 1997. Snitrosylation regulates apoptosis. Nature. 388, 432-3.

Miguel-Hidalgo, J.J., Vecino, B., Fernandez-Novoa, L., Alvarez, A., Cacabelos, R., 1998. Neuroprotective role of S12024 against neurodegeneration in the rat dentate gyrus. Eur Neuropsychopharmacol. 8, 203-8.

Miguel-Hidalgo, J.J., Alvarez, X.A., Cacabelos, R., Quack, G., 2002. Neuroprotection by memantine against neurodegeneration induced by beta-amyloid(1-40). Brain Res. 958, 210-21.

Moncada, S., Palmer, R.M., Higgs, E.A., 1991. Nitric oxide: physiology, pathophysiology, and pharmacology. Pharmacol Rev. 43, 109-42.

Park, Y.J., Jang, Y., Kwon, Y.H., 2010. Protective effect of isoflavones against homocysteine-mediated neuronal degeneration in SH-SY5Y cells. Amino Acids. 39, 785-94.

Paxinos, G., Watson, C., 1998. In: The rat brain in stereotaxic coordinates New York: Academic.

Pekny, M., Leveen, P., Pekna, M., Eliasson, C., Berthold, C.H., Westermark, B., Betsholtz, C., 1995. Mice lacking glial fibrillary acidic protein display astrocytes devoid of intermediate filaments but develop and reproduce normally. Embo J. 14, 1590-8.

Perez, J.L., Carrero, I., Gonzalo, P., Arevalo-Serrano, J., Sanz-Anquela, J.M., Ortega, J., Rodriguez, M., Gonzalo-Ruiz, A., 2010. Soluble oligomeric forms of beta-amyloid (Abeta) peptide stimulate Abeta production via astrogliosis in the rat brain. Exp Neurol. 223, 410-21. 
Picherit, C., Coxam, V., Oudadesse, H., Martini, B., Gaumet, N., Davicco, M.J., Lebecque, P., Miller, S., Irrigaray, J.L., Barlet, J.P., 2000. Dihydrotestosterone prevents glucocorticoid-negative effects on fetal rat metatarsal bone in vitro. Biol Neonate. 77, 181-90.

Piermartiri, T.C., Figueiredo, C.P., Rial, D., Duarte, F.S., Bezerra, S.C., Mancini, G., de Bem, A.F., Prediger, R.D., Tasca, C.I., 2010. Atorvastatin prevents hippocampal cell death, neuroinflammation and oxidative stress following amyloid-beta(1-40) administration in mice: evidence for dissociation between cognitive deficits and neuronal damage. Exp Neurol. 226, 274-84.

Ren, R., Zhang, Y., Li, B., Wu, Y., 2011. Effect of beta-amyloid (25-35) on mitochondrial function and expression of mitochondrial permeability transition pore proteins in rat hippocampal neurons. J Cell Biochem. 112, 1450-7.

Resende, R., Pereira, C., Agostinho, P., Vieira, A.P., Malva, J.O., Oliveira, C.R., 2007. Susceptibility of hippocampal neurons to Abeta peptide toxicity is associated with perturbation of $\mathrm{Ca} 2+$ homeostasis. Brain Res. 1143, 11-21.

Rodriguez, J.J., Olabarria, M., Chvatal, A., Verkhratsky, A., 2009. Astroglia in dementia and Alzheimer's disease. Cell Death Differ. 16, 378-85.

Rowland, I., Faughnan, M., Hoey, L., Wahala, K., Williamson, G., Cassidy, A., 2003. Bioavailability of phyto-oestrogens. Br J Nutr. 89 Suppl 1, S45-58.

Sofroniew, M.V., Vinters, H.V., 2010. Astrocytes: biology and pathology. Acta Neuropathol. 119, 7-35.

Song, M.S., Baker, G.B., Todd, K.G., Kar, S., 2011. Inhibition of beta-amyloid1-42 internalization attenuates neuronal death by stabilizing the endosomal-lysosomal system in rat cortical cultured neurons. Neuroscience. 178, 181-8.

Stepanichev, M.Y., Onufriev, M.V., Yakovlev, A.A., Khrenov, A.I., Peregud, D.I., Vorontsova, O.N., Lazareva, N.A., Gulyaeva, N.V., 2008. Amyloid-beta (25-35) increases activity of neuronal NOsynthase in rat brain. Neurochem Int. 52, 1114-24.

Tabarelli, Z., Berlese, D.B., Sauzem, P.D., Mello, C.F., Rubin, M.A., 2003. Antinociceptive effects of Cremophor EL orally administered to mice. Braz J Med Biol Res. 36, 119-23.

Tillement, L., Lecanu, L., Papadopoulos, V., 2011. Alzheimer's disease: effects of beta-amyloid on mitochondria. Mitochondrion. 11, 13-21.

Tsai, T.H., 2005. Concurrent measurement of unbound genistein in the blood, brain and bile of anesthetized rats using microdialysis and its pharmacokinetic application. J Chromatogr A. 1073, 317-22.

Valles, S.L., Borras, C., Gambini, J., Furriol, J., Ortega, A., Sastre, J., Pallardo, F.V., Vina, J., 2008. Oestradiol or genistein rescues neurons from amyloid beta-induced cell death by inhibiting activation of p38. Aging Cell. 7, 112-8.

Valles, S.L., Dolz-Gaiton, P., Gambini, J., Borras, C., Lloret, A., Pallardo, F.V., Vina, J., 2010. Estradiol or genistein prevent Alzheimer's disease-associated inflammation correlating with an increase PPAR gamma expression in cultured astrocytes. Brain Res. 1312, 138-44.

Wyss-Coray, T., Loike, J.D., Brionne, T.C., Lu, E., Anankov, R., Yan, F., Silverstein, S.C., Husemann, J., 2003. Adult mouse astrocytes degrade amyloid-beta in vitro and in situ. Nat Med. 9, 453-7.

Yun, H.Y., Dawson, V.L., Dawson, T.M., 1997. Nitric oxide in health and disease of the nervous system. Mol Psychiatry. 2, 300-10. 


\section{Figure legends}

Figure 1. Micrographs of hippocampal sections stained with cresyl violet (A1-C1) or with antibodies against $A \beta_{1-40}(A 2-C 2)$ or GFAP (A3-C4). Sections from sham-operated rats (A1A3) showed the following: normal morphology (A1), no $\mathrm{A} \beta_{1-40}$ immunoreactivity (A2), and some $\mathrm{GFAP}^{+}$cells (A3). Injection of $\mathrm{A} \beta_{1-40}(2 \mathrm{nM})$ into the hippocampus led to complete degeneration of neurons in DGlb (B1-B2), aggregation of $A \beta_{1-40}$ (B2; arrowheads), and intracellular expression of GFAP in a large area of the hippocampus (B3). Sections from genistein-treated (gavage, single dose of $10 \mathrm{mg} / \mathrm{kg}$ ) A $\beta_{1-40}$-injected rats showed partial degeneration in DGlb (C1-C2), no $\mathrm{A} \beta_{1-40}$ immunoreactivity (C2), and the $\mathrm{GFAP}^{+}$cells (C3) exhibited morphology (C4) that differed from that of cells in hippocampal sections from shamoperated (A4) and A $\beta_{1-40}$-injected (B4) rats. Magnification: x40 (A1-C1); x100 (A2, C2); x 200 (B2, A3-C3); x 630 (A4-C4).

Figure 2. Mean numbers of neurons in subdivisions of hippocampus, counted in five sections/animal. Treatments: sham, normal saline was injected into hippocampus $(\mathrm{n}=5)$; sham + genistein, genistein $\left(10 \mathrm{mg} / \mathrm{kg}\right.$ in $0.5 \mathrm{ml}$ of Cremophor $\left.{ }^{\circledR} \mathrm{EL}\right)$ was given by gavage before sham operation $(\mathrm{n}=5) ; \mathrm{A} \beta_{1-40}$, the peptide $(2 \mathrm{nmol} / 4 \mu \mathrm{l})$ was injected into hippocampus $(\mathrm{n}=6) ; \mathrm{A} \beta 1$ $40^{+}$genistein, genistein was given before injection of the peptide $(n=6) ; A \beta 1-40+$ Cremophor EL, Cremophor ${ }^{\circledR}$ EL was administered by gavage before injection of the peptide $(n=4)$. Values are means \pm SEM. Data are shown for the following hippocampal areas: CA1 $(2 \mathrm{~A}), * P=0.03$ (vs. sham) and ${ }^{* *} P=0.03$ (vs. sham + genistein); CA3 (2B), $* P=0.002$ (vs. sham) and $* * P<$ 0.0001 (vs. sham + genistein); DGlb (2C), ${ }^{*} P<0.0001$ (vs. sham), ${ }^{*} P<0.0001$ (vs. sham + genistein), $\S \S P=0.03$ (vs. $\mathrm{A} \beta_{1-40}$ ), and $\S P=0.02$ (vs. $\mathrm{A} \beta_{1-40}$ ). 
Figure 3. Micrographs showing iNOS (A1, B1) and nNOS (A2, B2) immunoreactive cells (arrows) in the hippocampus of sham-operated (A1, A2) and $A \beta_{1-40}$-injected (B1, B2) rats. CA1 is shown in A1 and B1, and DGmb in A2 and B2. Magnification: x400 (A1-B1); x600 (A2-B2).

Figure 4. Number of iNOS (A) and nNOS (B) immunoreactive cells in the hippocampus counted in three sections/animal. Treatments: sham, normal saline was injected into the hippocampus (n $=5)$; sham + genistein, genistein $\left(10 \mathrm{mg} / \mathrm{kg}\right.$ in $0.5 \mathrm{ml}$ of Cremophor $\left.{ }^{\circledR} \mathrm{EL}\right)$ was given by gavage before sham operation $(\mathrm{n}=5) ; \mathrm{A} \beta_{1-40}$, the peptide $(2 \mathrm{nmol} / 4 \mu \mathrm{l})$ was injected into the hippocampus $(\mathrm{n}=6) ; \mathrm{A} \beta_{1-40}{ }^{+}$genistein, genistein was administered before injection of the peptide $(n=6) ; A \beta_{1-40}{ }^{+}$Cremophor EL, the vehicle was given by gavage before injection of the peptide $(\mathrm{n}=4)$. Values are means \pm SEM. iNOS,$+ * P=0.01\left(\right.$ vs. sham); $\mathrm{nNOS}+,{ }^{*} P=0.0001$ (vs. sham + genistein) and $* * P=0.01\left(\right.$ vs. A $\left.\beta_{1-40}\right)$.

Figure 5. Mean intensity of GFAP positive immunoreactivity is shown in sham operated, $A \beta_{1-40}$ injected and $\mathrm{A} \beta 1-40$ injected- genistein treated rats. Values are means $\pm \mathrm{SEM}$. $* P=0.0006$ (sham vs. $\mathrm{A} \beta) ; * * P=0.02\left(\mathrm{~A} \beta_{1-40}\right.$ vs. $\mathrm{A} \beta_{1-40}+$ genistein $)$

Figure 6. Homogeneous pink matrix after cresyl violet staining (A) and positive immunoreactivity to $A \beta_{1-40}$ antibodies (B) in DGlb of rats injected with $A \beta_{1-40}$ in hippocampus. 